intensity in their overtones. There may be a difference in number, but this does not appear to affect the question of whether the tones of the string form an appreciable part of the consonant note of the violin.)

If a vibrating tuning-fork is placed in contact with the wood of a violin, the instrument reinforces the tone of the fork; but the vibrations of the wood are here much less powerful than in the case of the string, and consequently the instrument only feebly asserts its own timbre. A very ordinary violin will reinforce the tone of a fork almost as perfectly as a masterpiece of Cremona.

I therefore take it that the reinforcement of the tone of the fork is chiefly the result of resonance, and that the intensity of the tone of the violin is due to the reinforcement of the tones of the string itself by resonance, plus the reinforcement contributed by the tones of the pine and sycamore, and that the latter determine the timbre of the instrument.

The tones of the pine and sycamore are also reinforced by resonance, in the same way as those of the string.

June 2.

W. B. Coventry.

The "Armorl" Electro-Capillary Relay.

ON p. I29 of vol. Ixv. of NATURE, a description is given of an electro-capillary relay. The writer states that the actual apparatus was not seen by him, "but only a working model." It would be highly interesting to know the exact meaning of this expression. Does it mean a model which will work, or only a model in which the different parts of the apparatus are shown, say, in wood or cork or any other sulstance. In the illustration, the mercury when acted on electrically is shown as moving the lever of a relay. A well-made capillary electrometer is highly sensitive to a small change of potential, but the movement of the mercury column is so minute that it is very difficult to see how any lever of a relay could possibly be worked by means of its movement. Some further information about the "Armorl" relay would, I feel sure, be acceptable to many, showing the potential difference required to cause the mercury to work the lever $k$, and also the approximate E.M.F. set up at, say, ten miles from the sending station of a wireless telegraphic system.

J.-S.

Prekistoric Pygmies in Silesia.

UNDER the above heading, Prof. G. Thilenius, of the University of Breslau, has recently (Globus, Bd. lxxxi. No. I7) made an important contribution to European ethnology. His deductions result from an examination of a quantity of osseous remains preserved in the Museum of Silesian Antiquities at Breslau, consisting of four groups obtained at different sites in the region between Breslau and the Zobten. They are, unfortunately, very fragmentary ; but it has been ascertained that they are the remains of a number of persons of both sexes, all adult and all of very short stature. The mean height of one group is about 4 feet 8 inches ( $1429 \mathrm{~m}$ ) ), of two others about 4 feet I I inches (I.496 m.; I.506 m.), and of the fourth about 5 feet $\left\{{ }^{\circ} 523 \mathrm{~m}\right.$.). With these Prof. Thilenius compares the remains of the Swiss pygmies described by Prof. Kollmann, of Basel, who estimates their height as ranging between 4 feet $5 \frac{1}{2}$ inches $(\mathrm{r} \cdot 355 \mathrm{~m}$.) and 4 feet $\mathrm{II}$ inches ( $1499 \mathrm{~m}$.), and comparison is also made with the similar remains found at Egisheim (in Lower Alsace, near Colmar), which belonged, according to Herr Gutmann, to people whose stature ranged from about 3 feet $1 \mathrm{I}$ inches ( $\mathrm{I} \cdot 200 \mathrm{~m}$.) to something under 5 feet $\left(\mathrm{I}^{\cdot}{ }^{\circ} 20 \mathrm{~m}\right.$.). Further, the museum at Worms furnishes the remains of an individual of the estimated height of 4 feet 9 inches ( $1 \cdot 445 \mathrm{~m}$.). In all these cases, the bones show no trace of any pathological degeneration, and the consequent inference is that they represent a special race of low-statured men, or dwarfs. Profs. Kollmann and Thilenius seem to prefer the term "pygmy" as most appropriate in denoting a special race, "dwaif" (Zwerg) being regarded as applicable to abnormal specimens of a race of ordinary size. Most writers, however, make no such distinction ; and, indeed, "pygmy" is far from being strictly accurate when applied to people of 4 or 5 feet in height. Prof. Windle states that a people may be described as "pygmy" in which the average male stature does not exceed I $450 \mathrm{~m}$. (4 feet 9 inches).

Prof. Thilenius gives a wide range for the period in which those little people lived. While those of the Rhine valley are placed far back in time, some of the Silesian dwarfs are NO. I7O2, VOL. 66] assumed to have been contemporaneous with the Romans and the Slavs, the most recent being placed at about a thousand years ago. But, before arriving at anything like a final conclusion on any of the questions relating to the mid-European pygmies, Prof. Thilenius desires a much greater acccumulation of evidence in the shape of skeletal remains, and there is good reason to hope that this will be forthcoming in due time. Most of our information on the subject has been obtained within recent years, and fresh evidence can hardly fail to present itself to investigators in the future.

David MacRitchie.

\section{Flames from Mud on a Sea-Shore.}

WE should like to draw your attention to the following spectacle which some of us witnessed on the sea-shore at Blundellsands on Thursday evering, June 5, at about eight o'clock.

The evening was dull and grey, a strong north-westerly wind was blowing in from the sea and the tide was flowing in. In the distance we first saw smoke with frequent jets of fire bursting forth from the mud of a shallow channel. Drawing near, we perceived a strong sulphurous odour, and saw little flames of fire and heard a hissing sound as though a large quantity of phosphorus was being ignited. It was impossible to detect anything which caused the fire, only the water where the flames appeared had particles of a bluish hue flsating on the surface. The area over which the tiny flames kept bursting forth was about 40 yards.

A gentleman present stirred up the mud with his walkingstick, and immediately large yellow flames nearly 2 feet in length and breadth burst forth. The phenomenon lasted some time, until the tide covered the part and quenched the fire. As we returned from our walk the atmosphere was impregnated with a strong odour of sulphur. An old resident of Blundellsands, who also witnessed the sight, said he had never before seen anything of a similar nature.

9 Agnes Road, Blundellsands, near Liverpool, June 8.

\section{Cuckoo's Egg Thrown out of Bunting's Nest.}

ON the morning of May $25 \mathrm{I}$ found a nest of the reed bunting (Emberiza schoeniclus) with a cuckoo's egg in it besides three eggs of the bunting itself. When I took some friends to see it two or three hours later, the hen bird was sitting on the three eggs, but the cuckoo's egg was lying smashed outside the nest. It is impossible that any person could have broken it, for there were no traces of bootmarks in the soft mud on the side of the dyke where the nest was, besides it being very unlikely for anyone to have passed the spot during the short time I was away. It would interest me to know if any of your readers are acquainted with cases of small birds pitching the cuckoo's egg out of the nest instead of hatching it in the orthodox style.

Higham, May 27.

T. G.

\section{VOLCANIC ERUPTIONS IN THE WEST INDIES}

$\mathrm{I}$ the notes already published relating to the disasters which so recently overwhelmed Martinique and St. Vincent, reference has twice been made to the possible connection between seismic efforts and displays of volcanic activity. In connection with this, it has been suggested that had the sudden movements which on April I9 shattered cities in Guatemala been postponed, Mont Pelée and La Soufrière might still have been quiescent. By this it is not intended to convey the idea that if we take earthquakes generally and compare the registers of the same with the registers of volcanic eruptions we shall recognise any direct connection between the two. In Japan there are annualiy at least Iooo distinct earth shakings, but years may pass without the record of a volcanic eruption. Mount Fuji in that country has remained quiescent for the last 195 years, during which period it has been shaken at least 15,000 times, but in spite of this repeated aggravation the mons excelsus et singularis of Dai Nippon still watches peacefully over thirteen provinces round its base. 